DOI: 10.20472/EFC.2021.015.013

\author{
ANNA SKÓRSKA \\ University of Economics in Katowice, Department of Forecasting and Labour Analysis, Poland
}

\title{
WORK-LIFE BALANCE DURING THE COVID-19 PANDEMIC
}

\begin{abstract}
:
The article is a discussion concerning the essence and importance of reconciliation between work and family life during the COVID-19 pandemic The lack of harmony between various spheres of life brings many negative consequences, both at the micro (individual, organizational) as well as macro (society) level. Too many hours spent at work can lead to employee fatigue, dissatisfaction and absenteeism. On the other hand, problems in private life can affect the efficiency of employees. Considering the above, the purpose of the article is to present the essence of the conflict between work and private life in the time of the COVID-19 pandemic as an important element of the quality of life. The implementation of the goal formulated in this way required the following research questions:

- $\square$ Has the pandemic influenced the assessment of the work-life balance?

- $\square$ Has the pandemic affected the satisfaction with the amount and way of spending free time?

- $\square$ Are there any differences between women and men?

Considering that the measurement of work life balance as well as the impact of this phenomenon on quality of life is problematic the research, using the diagnostic survey method, was conducted in Poland in December 2020. The survey questionnaire was developed by the employees of the Department of Forecasting and Labor Market Analysis at the University of Economics in Katowice. Due to the limited volume of the article, the author decided to analyze only some of the results with particular emphasis on the gender of the respondents. It should be emphasized that despite many changes during last decades, in many families the division of responsibilities and tasks remains unequal. That is why the conflict between work and family life is particularly felt by women and the consequences of this phenomenon have increased during the COVID-19 pandemic.
\end{abstract}

\section{Keywords:}

work life balance, COVID-19 pandemic, women

JEL Classification: J01, J16, J81 


\section{INTRODUCTION}

The COVID-19 pandemic has caused many changes in all spheres of human life, we are struggling with many inconveniences in the professional sphere and great uncertainty also in other areas. The new reality requires effective and thoughtful actions, both for themselves, but also for families, colleagues, employees and employers. It requires the reorganization of the current routine, established habits, redefinition of priorities, sometimes even a reevaluation of the current life in order to return to normalcy as soon as possible, which will no longer be the norm from before the pandemic. Maintaining a balance between all spheres of life, and especially between work and family life, is particularly difficult in these conditions.

In the literature for several decades, it has been indicated how important is the balance between professional career and free time, devoted to yourself and the family. The lack of harmony between various spheres of life brings many negative consequences, both at the level of the individual, as well as organization and society as a whole. Too many hours spent on professional duties may lead to excessive employee fatigue, dissatisfaction with the work performed, increased absence and conflicts in the family. On the other hand, problems in private life the source of which is professional work may adversely affect the efficiency of employees. In order to reduce the consequences of this type of conflict, which were especially intense in the 1980 s and 1990s, various instruments were introduced to promote balance in the life of the employee. It should be emphasized that they still remain attractive, although understandably they require adaptation to the changing socio-economic conditions. Moreover, the pandemic, and as a consequence of this phenomenon shift to work-from-home, where children also learn remotely, showed these difficulties in a particularly vivid light.

Taking the above into account, the aim of the article is to present the essence of the conflict between work and family life in the time of the COVID-19 pandemic as an important element of the quality of life.

The implementation of the goal formulated in this way required the following research questions:

- Has the pandemic influenced the assessment of the work-life balance?

- Has the pandemic affected the satisfaction with the amount and manner of spending free time?

- Are there any differences between women and men?

The theoretical considerations presented in the article and the analysis of the obtained research results are an attempt to answer those questions.

\section{LITERATURE REVIEW}

Work and family life are undoubtedly the two most important spheres of human functioning. After many years of focusing on a professional career as a determinant of success in life, people began to notice that the lack of harmony between work and private life affects not only productivity at work but also broadly understood happiness and satisfaction with the life of an individual. One of most widely cited definition of work-family conflict states that "it is a form of interrole conflict in which the role pressures from the work and family domains are mutually incompatible in some respect. That is, participation in the work (family) role is made more difficult by virtue of participation in the family (work) role". (Greenhaus \& Beutell, 1985, p. 77). This conflict may by a source of stress and takes two basic forms: 
- work to family conflict,

- family to work conflict, that may assume the form of time-based; strain-based and behaviour-based conflict.

As the consequence of noticing and understanding this conflict, at the turn of the 1970s and 1980s, The Work-Life Balance (WLB), sometimes also called Work-Family Balance concept was created in the United States. It is a complex phenomenon, that is not precisely defined (lacking in a universal definition), therefore researchers consider and analyze different aspects of it. However, they mainly focus on the causes and consequences, programs and actions promoting WLB.

The analysis of numerous definitions of work life balance shows that it is primarily the ability to harmoniously combine various aspects of life, such as: work, family, home, social activity and individual hobby [Burke, 2004, Carlson, Grzywacz, Zivnuska, 2009, Milner, 2009, s. 1-2; Felsted i in., 2002, Skórska, 2019]. These aspects are included for example in Kirchmeyer's (2000) definition who views work-life balance as "achieving satisfying experiences in all life domains, and to do so requires personal resources such as energy, time, and commitment to be well distributed across domains". In a similar way, Clark defines work-family balance as "satisfaction and good functioning at work and at home with a minimum of role conflict" (Clark, 2000 , p. 349). Continuing this way of defining WLB, it is conceptualized by Grzywacz and Carlson (2007, p.458) as "the accomplishment of role related expectations that are negotiated and shared between an individual and his/her role related partners in the work and family domains".

Defining balance in terms of satisfaction raises practical problems - what does this mean in practice? How can this balance be achieved? How can it be measured? The problem arises when determining what "balance" exactly is - how can this term be defined and applied. It is difficult to imagine a balance in the situation of a rigid, equal division between work and leisure time (in a 1: 1 ratio), especially nowadays, when the boundaries between these spheres of life are more and more difficult to grasp. Time balance is maintained when people feel they are spending the right amount of time at work and appropriate amount of time with the family and other social commitments. On the other hand, time conflict occurs when the time required by the family competes with work. Treating these spheres of life separately and in opposition leads to frustration that you either work too much and "live" too little, or vice versa. Therefore, when looking for a balance, individual spheres of life should be treated as complementary to each other, with the same meaning [Skórska, 2021, Winslow, 2005, Edlund, 2007, Kossek, 2016]. Achievement the balance is favored by their harmonious combination, allowing for an increase of life satisfaction. It is a long standing goal of EU employment and social policies [OECD 2001; Jacobs, Gerson 2004]. It is also an element of the Europe 2020 strategy that should not only to enable more individuals to join the workforce, but also to promote greater gender equality. However, it should be stressed that finding a work-life balance is a challenge for both employers and employees, especially working parents. This is especially difficult during the pandemic, which has forced many people to reorganize their lives [Schieman, Badawy, Milkie, Bierman, 2021].

\section{METHODOLOGY}

The measurement of work-family conflict and work-life balance as well as the impact of this phenomenon on quality of life is problematic [Dex, Bond, 2005]. There are some measures to assess work-family conflict such as: the Work-Family Strains and Gains [Marshalland Barnett, 1993], the Work-Family Balance Scale [Wooden 2003; Zhang et al.2012], the National Work-Life 
Balance Index [Fernandez-Crehuet et al, 2016]. Some researchers (McGinnity and Whelan, 2009), have dealt with the issue of comparative work-life conflict in Europe, using the European Social Survey.

One of the common used measure is a "Better-Life" index proposed by the OECD. It is an interactive tool that allows to compare well-being, focusing on eleven topics, such as education, housing, life satisfaction, jobs, the environment, and so on [www1]. One of them is WLB index, based on the variables such as:

- the share of the labor force that works very long hours (more than $50 \mathrm{~h}$ a week)

- the time spent on "leisure and personal care" (defined, in contrast to paid or unpaid work, as spending time with friends, going to movies, pursuing hobbies, sleeping, eating, etc.).

The analysis of these variables was the background of our own research.

The implementation of the aim of the study required not only the use the statsitic data derived from OECD website, but also the diagnostic survey method. As far as data collection tools were concerned, the conduction of the research involved the use of anonimoy survey questionnaire, developed by the employees of the Department of Labor Market Forecasting and Analysis at the University of Economics in Katowice. Attached to each questionnaire there was covering letter that explained the objective of the survey and assured respondents of the confidentiality of their responses. Respondents were also informed that the survey's objective was to examine selected aspects of the quality of life of Poles. It was conducted in December 2020 on a representative group of 1,063 Poles. The sample size was determined based on the statistical equation.

The main objective of the study was to conduct a comprehensive assessment of the quality of life of Poles at an individual level. One of the key aspects of the research was the assessment of changes in the quality of life during the pandemic, with particular emphasis on the work and family balance. The results presented in the article are only part of a much more extensive research. Due to the limited volume of the study, the author decided to analyze the results with particular emphasis on the gender of the respondents.

Characteristics of the research group are presented in Table 1.

Figures 1 Socio-demographic characteristics of the research group

\begin{tabular}{|l|l|c|c|}
\hline \multirow{2}{*}{ Socio-demographic characteristics } & Number & $\%$ \\
\hline & Women & 559 & 52,4 \\
\cline { 2 - 4 } & Men & 508 & 47,6 \\
\hline \multirow{4}{*}{ Age } & $18-29$ & 215 & 20,2 \\
\hline & $30-44$ & 303 & 28,4 \\
\hline \multirow{4}{*}{ Educational attainment level } & $45-59$ & 260 & 24,4 \\
\cline { 2 - 4 } & 60 years and over & 288 & 27,0 \\
\hline & $\begin{array}{l}\text { Less than primary and primary } \\
\text { education }\end{array}$ & 25 & 2,3 \\
\cline { 2 - 4 } & lower secondary education & 110 & 10,4 \\
\cline { 2 - 4 } & $\begin{array}{l}\text { Upper secondary and post-secondary } \\
\text { non-tertiary education }\end{array}$ & 504 & 47,2 \\
\cline { 2 - 4 } & Tertiary education & 428 & 40,1 \\
\hline & Single persons (never in legal union) & 282 & 26,4 \\
\cline { 2 - 4 } & Married persons & 642 & 60,2 \\
\hline
\end{tabular}




\begin{tabular}{|l|l|c|c|}
\hline Marital status & Divorced persons & 70 & 6,6 \\
\cline { 2 - 4 } & Separated persons & 12 & 1,1 \\
\cline { 2 - 4 } & Widowed persons & 61 & 5,7 \\
\hline Place of residence & City & 846 & 79,3 \\
\cline { 2 - 4 } & Country & 221 & 20,7 \\
\hline \multirow{5}{*}{ Status on labour market } & Employed persons & 650 & 60,9 \\
\cline { 2 - 4 } & Unemployed persons & 61 & 5,8 \\
\cline { 2 - 4 } & Retirement & 224 & 21,0 \\
\cline { 2 - 4 } & Inactive persons because of disability & 40 & 3,7 \\
\cline { 2 - 4 } & Student & 48 & 4,5 \\
\cline { 2 - 4 } & Pupil & 20 & 1,9 \\
\cline { 2 - 4 } & Inactive persons for other reasons & 24 & 2,2 \\
\hline
\end{tabular}

Source: own calculation based on the research results

\section{RESULTS AND ANALYSIS}

Poland performs well in some measures of well-being in the Better Life Index such as personal security and education and skills, but below average in health status, income and wealth, social connections, civic engagement, subjective well-being, jobs and earnings, environmental quality, work-life balance and housing. The rank of WLB $(6,8)$, based on available selected data, confirms that the gap between Poland and other countries, especially such as Denmark or the Netherland remains wide.

During our own research, first of all, the respondents were asked to evaluate their level of satisfaction with work-life balance, as one of the key aspect of quality of life. It was measured by the scale 1-7, where "1"=I am very unsatisfied and 7=I am very satisfied.

It should be stressed that most respondents indicated that they are satisfied with their work-life balance. Only $11 \%$ indicated the lowest ratings (1-2), while over $29 \%$ - the highest ones (6-7). These answers were similar to the assessment of quality of life - only $6 \%$ of respondents were very unsatisfied with quality of their life, while over $26 \%$ were very satisfied. However, it should be stressed that gender was one of the determinant that differentiated the distribution of the answers. Most of women (especially employed and married ones) pointed lower rates of WLB compared to men. It may indicate that in many families duties and responsibilities are not evenly distributed. It means that women still have less leisure time than men and they more often experience the conflict between different spheres of their life. 


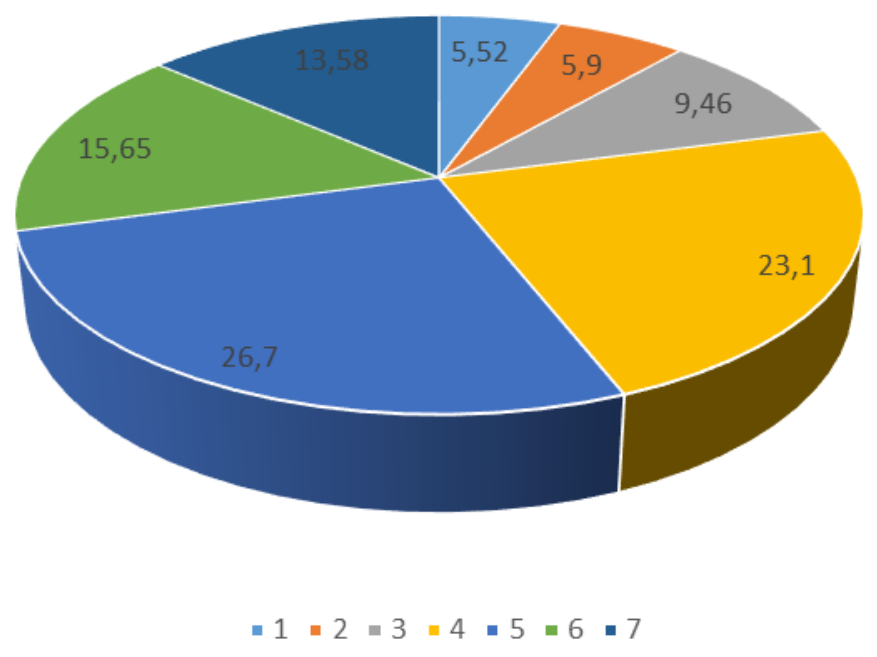

Figure 1 The assessment of work life balance - \%

Source: own calculation based on the research results

Considering that satisfaction is one of these outcomes that are frequently included in the definitions of balance, we tried to check if and how it changed during the pandemic. The respondents were asked to compare their opinions about WLB before and during the pandemic. It was measured by the scale from -3 to 3 , where "- 3 " = it definitely decreased, " 0 "- it did not change and $3=$ it definitely increased. The distribution of answers is presented on fig. 2.

As it can be seen - over half of men $(52,1 \%)$ indicated that they did not notice any change in their life, while such answer gave only $18 \%$ of women. Over $70 \%$ of women noticed that during the pandemic the harmony in their life worsened. Such answers were most common among divorced and separated women with upper secondary and tertiary educational level, aged 30-44 and 45-59. It may suggest that during the pandemic women more often had to combine family and work duties such as remote work, childcare, helping children in remote learning and other responsibilities. The COVID-19 pandemic has heightened the inequalities-both at work and at home - that women face daily. 


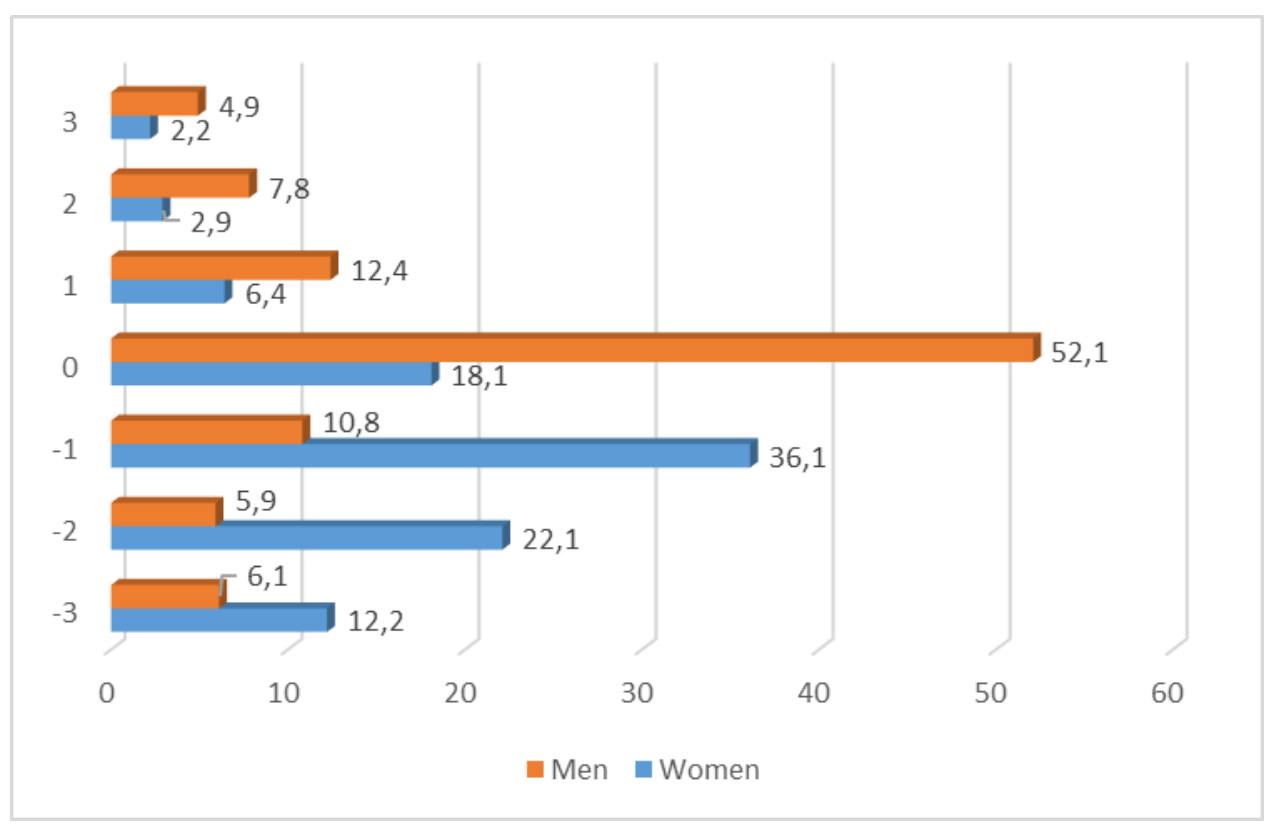

Figure 2 Change of work-life balance during the pandemic, by sex (\%)

Source: own calculation based on the research results

Assuming that one of the important aspect of work-life balance is the amount of time a person spends at work, the attention should be paid to the place of Poland in the OECD ranking. Research suggest that long work hours may influence personal health, jeopardise safety and increase stress. According to Eurostat [www2], the average working time per week in the EU-27 is 37 hours, however for example the Dutch work 30.4 hours a week, but Greeks almost 42 hours. Gender is one of the factors differentiating the average working time. For women, it is shorter - in 2019 in the EU-27 it exceeded 34 hours a week, while for men it was approximately 6 hours more. In the last decade, it has decreased slightly in most Member States. In countries with a long tradition of the welfare state model, favoring the balance between different spheres of life, such as Denmark or Germany, women on average work 31 hours a week, and in the Netherlands 25.5 hours. However, it should be emphasized, that there are countries, e.g. Bulgaria, where it is much higher, reaching 40 hours. weekly, see fig. 3 . 


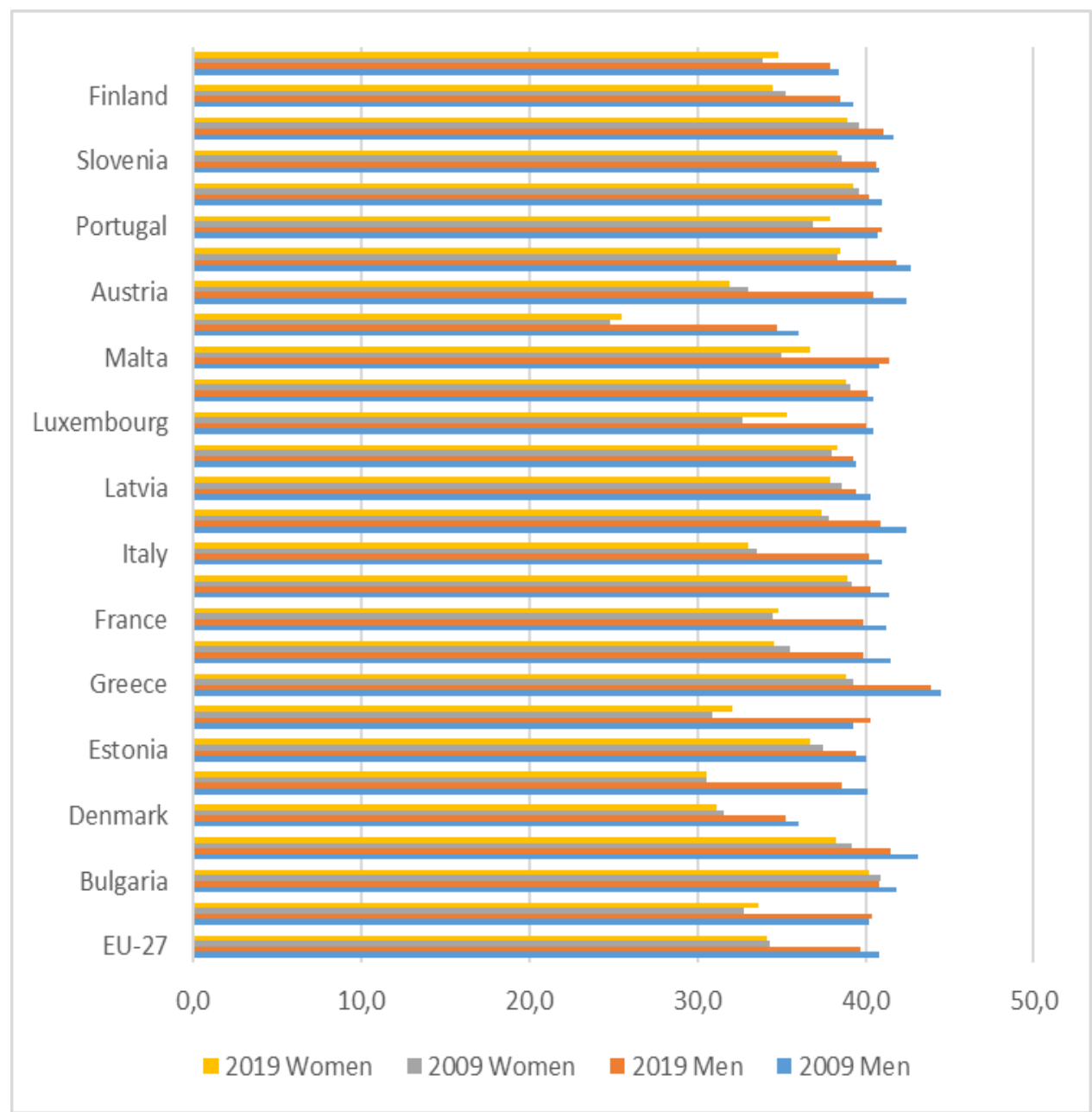

Figure 3 Average number of usual weekly hours of work in main job, by sex in 2009 and 2019

Source: www2

When analyzing the average working time, it should be emphasized that, according to Eurostat, more than $8 \%$ of EU workers spend more than 50 hours at work. weekly. In Lithuania, this percentage does not exceed $0.7 \%$, while in Greece it is higher by almost $16 \mathrm{pp}$, which confirms the disproportions between individual countries, see fig. 4. Although it has decreased in the last decade, managers (26.5\% in the EU) and those working in agriculture, forestry and fisheries (25.8\%) remain the groups most exposed to long working hours. In Poland, $6 \%$ of employees work very long hours (22 place in the ranking), less than the OECD average of $11 \%$. In this situation, it is difficult to combine professional and family life. In such situation, the amount and quality of leisure time is very important, and can bring additional physical and mental health benefits. In Poland, full-time workers devote $60 \%$ of their day on average, or 14.4 hours, to personal care (eating, sleeping, etc.) and leisure (socialising with friends and family, hobbies, games, computer and television use, etc.) - less than the OECD average of 15 hours and especially of France and the Netherlands (over 16 hours) [www1]. 


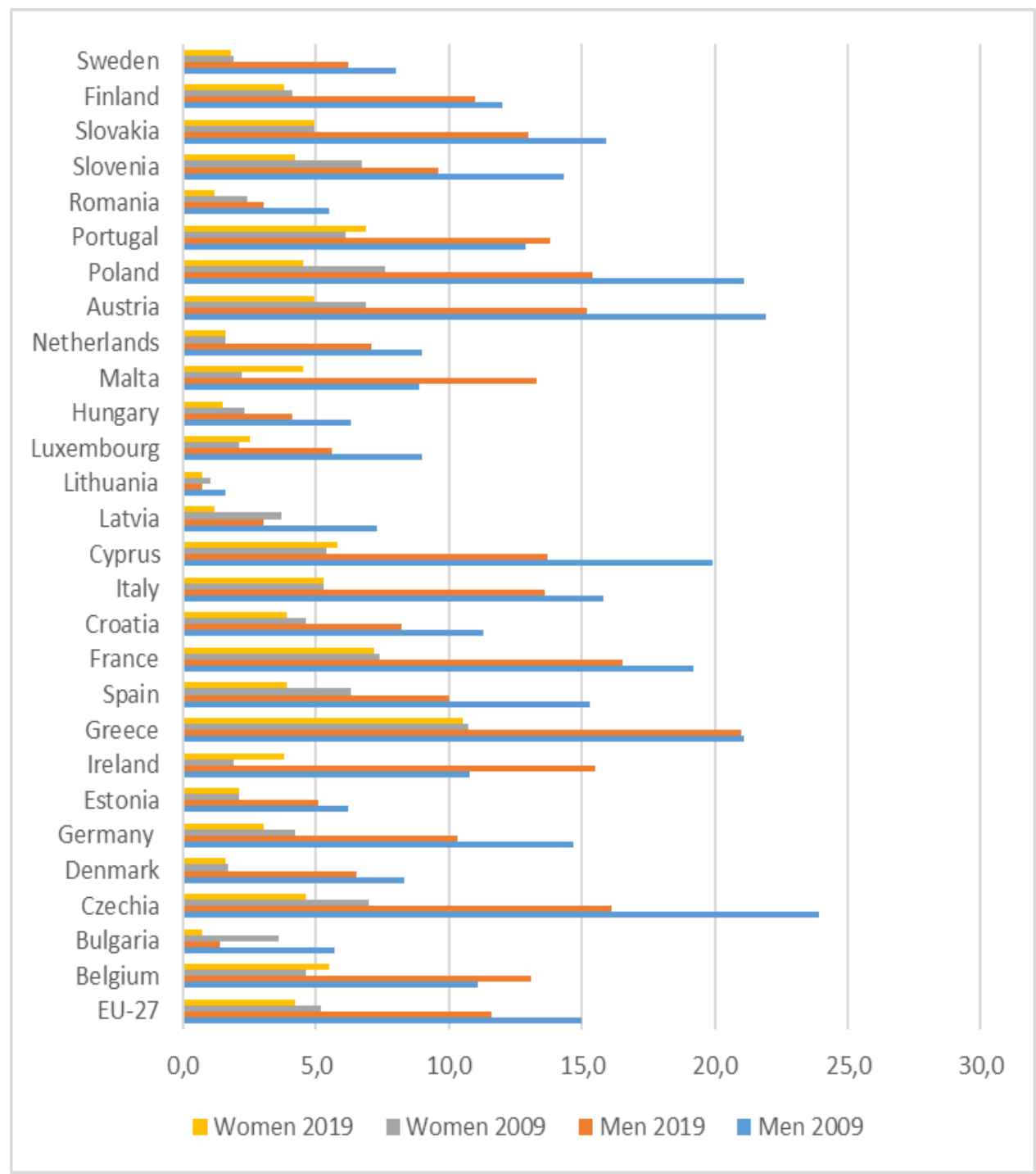

Figure 4 Long working hours in main job by sex, in 2009 and 2019

Source: www2

The satisfaction of amount of leisure time and the way of spending it were another analyzed aspects of WLB assessment. We tried to check if and how it changed during the pandemic using the same scale (from -3 to 3, where "-3"= it definitely decreased, "0"- it did not change and $3=$ it definitely increased). The distribution of answers is presented on fig. 5. 


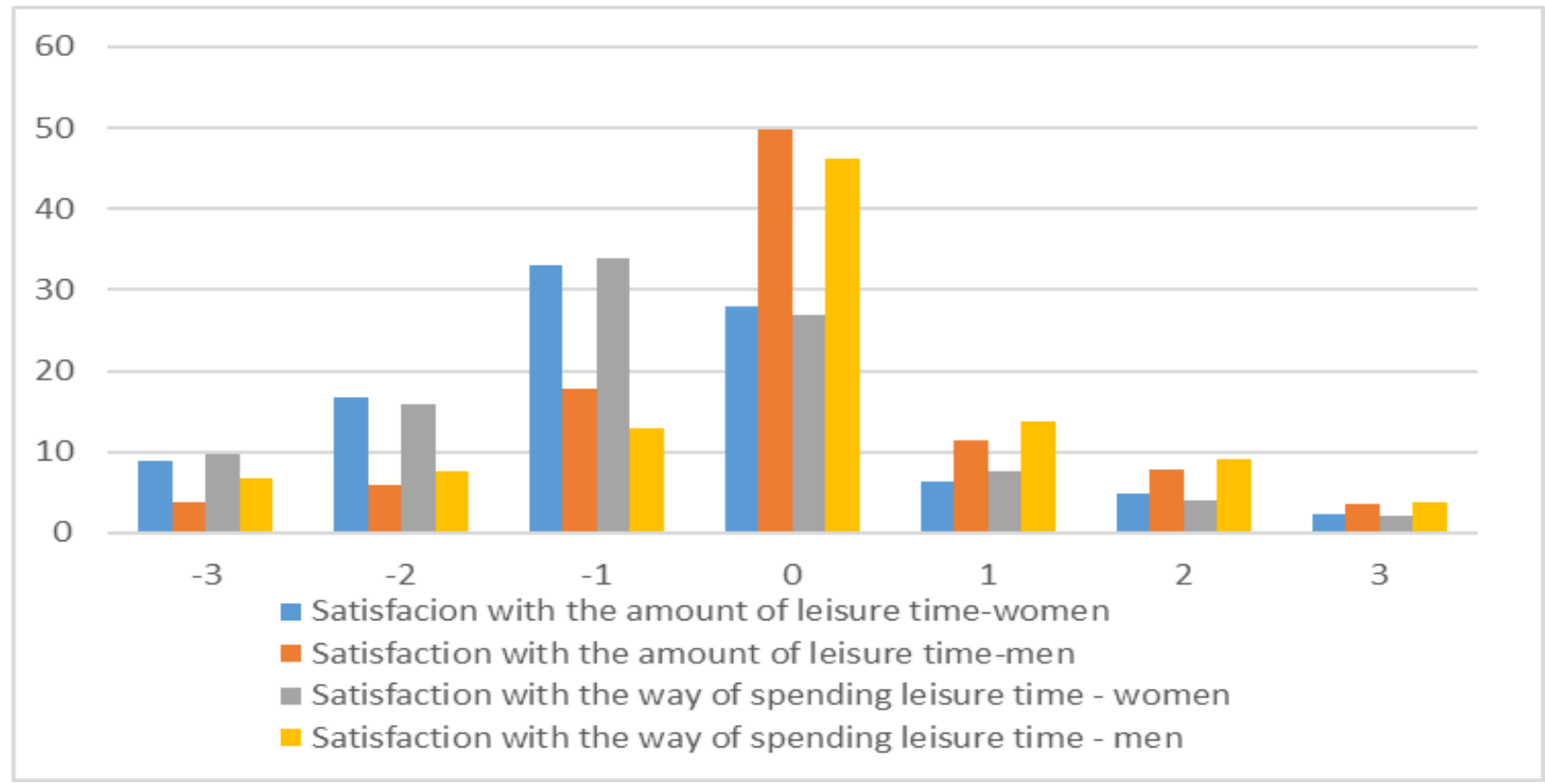

Figure 5 Satisfaction with the amount and way of spending leisure time, by gender (\%)

Source: own calculation based on the research results

It is not surprising that gender was once again a factor influencing the differentiation of responses. The level of satisfaction, both of amount and way of spending leisure time, was much lower among women than men. Almost $59 \%$ of women noticed that they have less leisure time and almost $60 \%$ of them responded that their satisfaction with the way of spending leisure time had worsened. Such answers were given by only $27 \%$ of men, while over $46 \%$ did not noticed any change. Data analysis from Eurostat confirms that during the pandemic the percentage of women working from home increased. Concentrating on the tasks performed while working remotely is more difficult because everything around can be treated as distractions - noise, lack of separate workplace, simultaneous work and childcare, helping the child in learning, television, telephone, using social media while working and performing other domestic duties. These activities consume a lot of time that should be spent on performing tasks at work. As a consequence, it is more difficult to separate the time devoted to work and other duties, which may have a negative impact on your free time.

\section{CONCLUSION}

Work-life balance concept emphasizes that a person realizes himself not only by his professional carrier, but also thanks to a successful personal life. Achieving balance in various areas of life is not only one of the priorities, but also a challenge that a person faces. Research confirms that the conflict between work and professional life is particularly visible among women. Despite many positive changes during last decades, the division of duties in families remains unequal, which affects the perceived satisfaction. Women still have less leisure time and the way of spending it does not satisfy them. 
The COVID-19 pandemic, during just a few months, influenced and changed many spheres of human life. Remote work, remote learning, childcare, staying at home 24/7 caused new problems of reconciliation of work and personal life that cannot be ignored by managers and employers. Due to those changes, but mainly because of the development of technology, the Internet and mobile devices, the concept of Work Life Integration (WLI), as an alternative to WLB, is increasingly used. The problem that is underlined in this concept is the fact that working time is not extended, but working and private time are not separated. Fewer and fewer employees can say that they are working "from to" because of the phones and e-mails on business matters after leaving the place of work are commonplace for many people. Such flexibility of work gives many opportunities, but at the same time makes the employee constantly available to his superiors and makes him unable to rest from work (because he never truly leaves it). Whatever concept you prefer, it's worth noting that the problem of reconciliation of work and private life is one of the key challenge of XXI century.

The future of work-life balance could take many different forms depending on economical, societal, and political changes. Regardless of the changes, the implementation of work-life balance programs requires appropriate actions at the level of the state, local authorities and enterprises. Some institutions such as trade unions, but also the media can play a helpful role in this process. Households themselves have a large opportunity to promote and implement the work life balance, especially in terms of cultural patterns related to the implementation of family and professional roles of men and women.

\section{References}

1 Burke R.J. (2004) Work and Family Integration, "Equal Opportunities International", Vol. 23,No. 1-2, s. $1-5$.

1. Clark S.C., (2000), Work/Family Border Theory: A New Theory of Work/Family Balance, Human Relations, 53 (6), s. 747-770.

2. Carlson, S.D., Kacmar, M.K. \& Williams, J.L. (2000), Construction and Initial Validation of a Multidimensional Measure of Work-Family Conflict, Journal of Vocational Behaviour, Vol. 56, pp. 249-276

3. Carlson, D.S., Grzywacz, J.G., and Zivnuska, S. (2009), Is work-family balance more than conflict and enrichment? Human Relations, 62, 10, pp.1459-1486.

4. Dex, S., Bond, S. (2005). Measuring work-life balance and its covariates. Work Employment \& Society, 91(3), 627-637.

5. Edlund,J. (2007). The work-family time squeeze: conflicting demands of paid and unpaid work among working couples in 29 countries. International Journal of Comparative Sociology, 48(6), 451-480.

6. Felstead A., Jewson N., Phizacklea A., Walters S. (2002), Opportunities to Work at Home in the Context of Work-life Balance, "Human Resource Management Journal", Vol. 12,No. 1, s. 54-76.

7. Fernandez-Crehuet J.M., Gimenez-Nadal I.,Reyes Recio L.E., The National Work-Life Balance IndexÓ: The EuropeanCase, Social Indicators Research (2016) 128, 341-359

8. Greenhaus, J. H., \& Beutell, N. J. (1985). Sources of conflict between work and family roles. Academy of Management Review, 10, 76-88. 
9. Greenhaus, H.J., Collins, M.K. \& Shaw, D.J. (2003), The relation between work-family balance and quality of life, Journal of Vocational Behaviour, Vol. 63, 2003, pp. 510-531

10. Grzywacz, J.G. and Carlson, D.S. (2007), Conceptualizing work-family balance: implications for practice and research, Advances in Developing Human Resources, 9, pp. 455471.

11. Jacobs, J. A., and Gerson, K. (2004).The Time Divide. Cambridge: Harvard University Press.

12. Kirchmeyer C., Work-life initiatives: Greed or benevolence regarding workers time, [in:] Trends in organizational behavior, red. C.L. Cooper, D.M. Rousseau, Wiley, Chichester 2000.

13. Kossek, E. E. (2016), Managing Work-Life Boundaries in the Digital Age. Organizational Dynamics 45(3):258-70

14. Marshall, N. L., \& Barnett, R. C. (1993). Work-family strains and gains among two-earner couples.Journalof Community Psychology, 21, 64-78.

15. McGinnity, F., \& Whelan, C. T. (2009). Comparing work-life conflict in Europe: Evidence from theEuropean social survey.Social Indicators Research, 93, 433-444.

16. OECD. (2001). Balancing work and family life: Helping parents into paid employment, Chapter 4.Employment Outlook

17. Schieman S., Badawy P.J., Milkie M.A., Bierman A. (2021), Work-Life Conflict During the COVID-19 Pandemic, Sociological Research for a Dynamic WorldVolume 7: 1-19

18. Skórska A. (2021), Równowaga między pracą i życiem pozazawodowym - wyzwanie dla pracujących rodziców (w:) Internacjonalne relacje we współczesnym świecie, UE Katowice.

19. Skórska A. (2019), Is WLB Important for the Generation Y? in: Economic and Social Development 38th International Scientific Conference on Economic and Social Development "Sustainability from an Economic and Social Perspective", Book of Proceedings, ed. K Hammes, M. Machrafi, A. Samodol, Rabat, s. 160-169.

20. Winslow, Sarah. 2005. "Work-Family Conflict, Gender, and Parenthood, 1977-1997." Journal of Family Issues 26:727-55

21. Wooden, M. (2003).Balancing work and family at the start of the 21st century: Evidence from wave 1 of theHILDA survey. (Paper presented to the pursing opportunity and prosperity: The 2003 Melbournelnstitute Economic and Social Outlook Conference, Melbourne)

22. Zhang, H., Yip, P. S. F., Chi, P., Chan, K., Cheung, Y. T., \& Zhang, X. (2012). Factor structure andpsychometric properties of the work-family balance scale in an Urban Chinese sample.Social Indi-cators Research, 105, 409-418.

23. [www1] https://www.oecdbetterlifeindex.org/topics/work-life-balance/

24. [www2] https://ec.europa.eu/eurostat 